\title{
Role of viruses and bacteria in acute wheezy bronchitis in childhood: a study of sputum
}

\author{
MARY E. C. HORN, SYLVIA E. REED, AND PAUL TAYLOR \\ Department of Microbiology, Brompton Hospital, and Medical Research Council Common Cold Unit, \\ Harvard Hospital, Salisbury, Wiltshire
}

SUMmARY Sputum, nasal swabs, and throat swabs were obtained from 22 children aged between 5 and 15 years during 72 attacks of wheezy bronchitis. A virus, most commonly a rhinovirus, was isolated in $49 \%$ of all episodes and in $64 \%$ of 22 severe episodes requiring treatment with corticosteroids; the isolation rate was higher early in the illness than later. Virus was recovered more often from sputum than from the nose or throat, suggesting that viral replication occurs freely in the lower respiratory tract: the cytological findings in sputum were compatible with an inflammatory response to viral infection. Pathogenic bacteria appeared to play a minor role compared with viruses, and routine antibiotic treatment was probably of little value in most cases. The significance of the results is discussed in relation to the pathogenesis of childhood wheezy bronchitis.

Wheezy bronchitis of childhood may be defined as an acute illness usually preceded by upper respiratory symptoms and characterised by cough and variable degrees of wheezing, breathlessness, and mucus expectoration. On auscultation high-pitched wheeze is audible over most parts of the chest in addition to medium crepitations or rhonchi. Various terms such as 'asthmatic bronchitis', 'exacerbations of asthma', or 'bronchitis with bronchospasm' have been used to describe this illness. Several studies have established that during these episodes common respiratory viruses can be isolated from the upper respiratory tract (McIntosh et al., 1973; Minor et al., 1974; Horn et al., 1975; Mitchell et al., 1976). Horn and Gregg (1973) and Horn et al. (1979) noted that certain children experience recurrent episodes of wheezy bronchitis and it seems clear that undetermined constitutional factors must influence the individual child's response to infection with common respiratory viruses. The pathogenic mechanisms underlying the cough, bronchoconstriction, and excess lower respiratory secretion that characterise this condition are unknown. It is possible either that the lower respiratory symptoms are a remote response to viral infection in the upper respiratory

MARY E. C. HORN, 6 Genoa Avenue, London SW15 6DY MRC Common Cold Unit, Harvard Hospital, Salisbury SYLVIA E. REED, member of scientific staff

Department of Microbiology, Brompton Hospital, London P. TAYLOR, chief medical laboratory scientific officer tract, or that they are a consequence of viral invasion of the bronchial mucosa.

We now describe a study designed to provide further evidence on this point. Sputum collected from children during attacks of wheezy bronchitis was examined in parallel with nasal and throat swabs using virological, bacteriological, and cytological techniques.

\section{Patients and methods}

Clinical methods. The study was carried out in a special asthma and bronchitis clinic held twice weekly for children in a general practice. Between October 1974 and April 1976 (excluding July and August 1975) each child attending for treatment of an episode of wheezy bronchitis, as defined above, was accepted for study provided he presented within 5 days of onset of the initial symptoms (upper or lower respiratory) and was able to expectorate sputum. 22 children (15 boys and 7 girls), aged between 5 and 15 years, satisfied these conditions; all had a history of recurrent wheezy bronchitis and were among those previously investigated by Horn et al. (1975). The number of episodes investigated per child ranged from one to 15.19 of the 22 children wheezed on exercise, on exposure to inhaled allergens, or with emotional upsets; the remaining 3 wheezed only during attacks of wheezy bronchitis. 17 of the 22 children gave positive reactions to at 
least one of 14 inhaled allergens used in skin prick tests. These children were defined as atopic and the remaining 5 as nonatopic; 3 of the nonatopic children were known to wheeze only during attacks of wheezy bronchitis. A family history of asthma or allergic rhinitis was present in 12 atopic children and 5 nonatopic ones; the remaining 5 children had no such family history but were atopic on prick testing.

Episodes were classified retrospectively according to severity on the basis of airflow obstruction and the need to give corticosteroids, judged clinically. Airflow obstruction was measured by the fall in peak expiratory flow (PEF) rate, expressed as a percentage of the predicted PEF for height (Godfrey et al., 1970). Episodes were classified as severe if treatment with corticosteroids was required for control or if the fall in PEF was at least $60 \%$; moderate episodes were those which did not require corticosteroids and in which PEF fell by $40-59 \%$; mild episodes were those in which the PEF fell by less than $40 \%$.

Appropriate bronchodilator or corticosteroid treatment was prescribed during the acute phase of the illness until prophylaxis with an oral bronchodilator and sodium cromoglycate or beclomethasone dipropionate aerosol could be resumed. Physiotherapy was an integral part of treatment and sputum samples were obtained by encouraging coughing during postural drainage and percussion.

As controls, 31 nasal and throat swabs collected from 17 children between acute attacks were also examined virologically, but control sputum samples could not be obtained.

The first sputum samples, nasal swabs, and throat swabs examined in each episode were collected at the child's first attendance, within 5 days of onset of respiratory symptoms, and before prescribing antibiotics or corticosteroids. Whenever possible a second nasal swab and sputum sample were obtained later in the illness, generally within 5 days of the first. If bacterial infection was thought likely on clinical grounds, penicillin, co-trimoxazole, or ampicillin (in order of frequency) was prescribed when the child first attended the clinic. One of these was prescribed at the second visit, after second samples had been collected, if the first samples had shown Streptococcus pyogenes in the throat or if there had been any pathogenic bacteria in the sputum and the clinical condition still warranted treatment.

Specimens for virological examination were kept chilled in transport medium and delivered to the laboratory within 4 hours. Throat swabs transported in Stewart's medium and sputum samples were examined bacteriologically, and the sputum was also examined cytologically.
Laboratory methods. The techniques for isolating viruses and Mycoplasma pneumoniae were as previously described (Horn et al., 1975), except that MRC-5 human embryo lung fibroblasts were substituted for WI-38 cells which were no longer obtainable. After inoculation into standard cultures, the remainder of each specimen was stored at $-70^{\circ} \mathrm{C}$ and later cultured in rhinovirus-sensitive HeLa cells (Strizova et al., 1974). Rhinoviruses were characterised by their typical cytopathic effect (cpe) and by their acid lability, but were not serotyped. No attempt was made to quantitate rhinovirus by titration, but the relative amount of virus present in the various types of specimens was assessed roughly by noting the day of development of rhinovirus cpe in the culture and calculating the means for nasal swabs and sputum samples. Organ cultures or other special techniques for isolation of coronaviruses were not used.

Throat swabs were cultured on blood agar and MacConkey agar incubated aerobically at $37^{\circ} \mathrm{C}$. Sputum was homogenised with pancreatin, shaken, and similarly cultured undiluted, and at a dilution of $10^{-4}$. Isolations of Streptococcus pneumoniae and Haemophilus influenzae were considered significant if the organisms were detected at a dilution of $10^{-4}$ : Staphylococcus aureus and $S$. pyogenes in any numbers were considered significant.

Sputum smears were stained with haematoxylin and carbol chromotrope 2R. The whole area of each specimen was examined by a single observer, and the prevalence of leucocytes, bronchial epithelial cells, and macrophages was estimated on an arbitrary scale $1+$ to $3+$. Eosinophils were assessed as an approximated percentage of the total cellular content: an arbitrary figure of at least $25 \%$ eosinophilia was considered abnormal, as were bronchial epithelial cells or macrophages scored as $1+$ or more and leucocytes as $2+$ or more.

\section{Results}

72 episodes of wheezy bronchitis were studied, of which 18 were classified as mild, 24 as moderate, and 30 as severe. Upper respiratory symptoms were present in all but one moderately severe episode. Rhinorrhoea was present in 71 episodes, pharyngitis in 39 , otitis media in 2 , sinusitis in 2 , pyrexia in 11, headache in 8 , and myalgia in 2 . Sputum samples were obtained at the first attendance in all but 2 episodes in which severe bronchospasm prevented expectoration; in these 2 , sputum was obtained at the second attendance. In a few episodes nasal or throat swabs could not be obtained. Second samples were obtained in 54 episodes: 42 within 5 days of the first, 11 within 8 days, and one after 15 days. 
Virology. One or more viruses were isolated in 35 $(49 \%)$ of the 72 episodes. The virus isolation rates in mild, moderate, and severe episodes were 17 , 54 , and $63 \%$ respectively, and in 22 severe episodes requiring corticosteroid treatment the recovery rate was $64 \%$. Table 1 shows the number of episodes yielding virus, with its source, and the Figure gives the rate of virus isolation for each category of specimen. Rhinoviruses predominated over all other agents and were recovered throughout the study. Influenza viruses were isolated only during the two main epidemic periods, December 1974 to January 1975 (influenza A), and January to March 1976 (influenza A and B). Of the 30 severe episodes

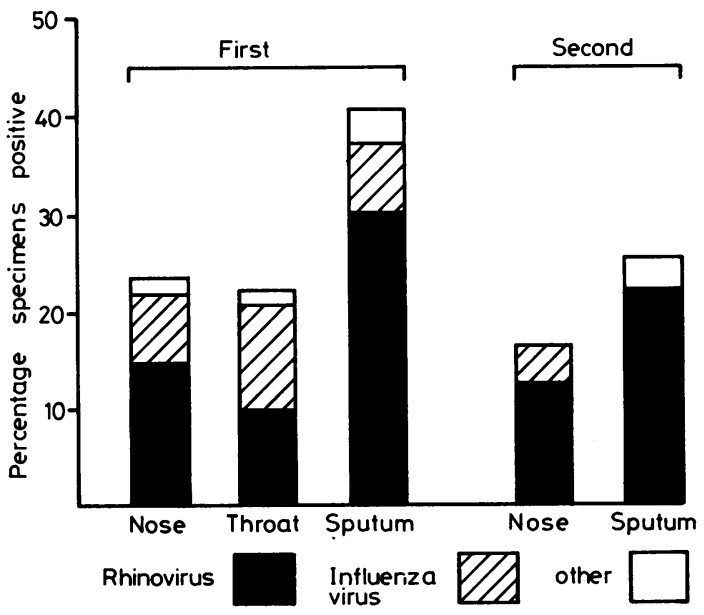

Figure Rates of isolation of rhinovirus, influenza virus, and other viruses (including $M$. pneumoniae) from various specimens. investigated, 12 were associated with rhinovirus alone or in combination with another agent, and 4 with influenza viruses.

The first sputum samples were the best source of virus, particularly rhinovirus: influenza viruses were more common in nasal and throat swabs than in sputum (Figure). $29(41 \%)$ isolates were obtained from 70 first sputum samples, 15 (23\%) from 64 first nasal swabs, and $14(22 \%)$ from 64 throat swabs. The overall isolation rate from first sputum samples was therefore significantly higher than from the first nasal or throat swabs $\left(P<0.05, \chi^{2}\right.$ test). The mean day of development of rhinovirus cpe in HeLa cells was 3.9 days for first sputum samples and 4.6 days for first nasal swabs, and in MRC-5 cells the corresponding figures were $5 \cdot 1$ and 8.0 days, indicating that the sputum probably contained more virus than the nasal swabs. The second samples, taken later in the illness, gave fewer isolates than the first, but again sputum showed more isolates than the nose. In only 3 episodes were second samples positive when first samples had been negative.

Only one of the 31 control swabs from the upper respiratory tract contained virus.

Bacteriology. 28 (39\%) of the 72 episodes showed significant bacterial isolations but, in 15 of these, the isolations were from throat swabs; only 3 sputum samples contained the same organism as was found in the throat swab. Only $12(17 \%)$ of 70 first sputum samples gave significant bacterial isolations (Table 2), and the episodes from which these samples were obtained were not distinguishable by any particular clinical feature. The bacteria isolated from sputum in 6 virus-positive episodes

Table 1 Isolation of viruses and M. pneumoniae from nasal swabs, throat swabs, and sputa collected during 72 episodes of wheezy bronchitis

\begin{tabular}{|c|c|c|c|c|c|c|c|c|c|}
\hline & \multirow{3}{*}{$\begin{array}{l}\text { Total no. of } \\
\text { episodes from } \\
\text { which agents } \\
\text { were isolated }\end{array}$} & \multicolumn{8}{|c|}{ Episodes in which an agent was isolated } \\
\hline & & \multicolumn{4}{|c|}{ From 1st sample } & \multicolumn{4}{|c|}{ From 2nd sample } \\
\hline & & $\begin{array}{l}\text { URT } \\
\text { only }\end{array}$ & $\begin{array}{l}\text { Sputum } \\
\text { only }\end{array}$ & $\begin{array}{l}\text { URT and } \\
\text { sputum }\end{array}$ & Total & $\begin{array}{l}\text { URT } \\
\text { only }\end{array}$ & $\begin{array}{l}\text { Sputum } \\
\text { only }\end{array}$ & $\begin{array}{l}\text { URT and } \\
\text { sputum }\end{array}$ & Total \\
\hline Rhinovirus & 20 & 3 & 7 & 10 & 20 & 2 & 8 & 2 & 12 \\
\hline Influenza $\mathbf{A}$ & 6 & 2 & $\mathbf{0}$ & 3 & 5 & 1 & $\mathbf{0}$ & $\mathbf{0}$ & $1 *$ \\
\hline Influenza B & 1 & $\mathbf{0}$ & $\mathbf{0}$ & 1 & 1 & $\mathbf{0}$ & 0 & 0 & $\mathbf{0}$ \\
\hline $\begin{array}{l}\text { Parainfluenza } 1 \\
\text { Respiratory }\end{array}$ & 2 & $\mathbf{0}$ & $\mathbf{0}$ & 1 & 1 & $\mathbf{0}$ & 1 & $\mathbf{0}$ & $1 *$ \\
\hline syncytial virus & 1 & 0 & 1 & 0 & 1 & 0 & 0 & $\mathbf{0}$ & 0 \\
\hline Adenovirus & 1 & 0 & 0 & 0 & 0 & $\mathbf{0}$ & 1 & $\mathbf{0}$ & $1 *$ \\
\hline Influenza A & & & & & & & & & \\
\hline $\begin{array}{r}\text { + rhinovirus } \\
\text { Parainfluenza } 3\end{array}$ & 2 & $\mathbf{0}$ & 2Rh & $11 \mathbf{A}$ & 2 & IIA & 0 & $\mathbf{0}$ & 1 \\
\hline $\begin{array}{l}+ \text { rhinovirus } \\
\text { M. pneumoniae }\end{array}$ & 1 & 0 & 1 PI3 & $1 \mathrm{Rh}$ & 1 & $\mathbf{0}$ & 1Rh & 0 & 1 \\
\hline+ rhinovirus & 1 & $1 \mathrm{Mp}$ & 0 & $1 \mathrm{Rh}$ & 1 & 0 & 0 & $1 \mathbf{R h}$ & 1 \\
\hline
\end{tabular}

*Episodes in which an agent was isolated from 2nd samples but not 1 st.

$\mathbf{R h}=$ rhinovirus; IA = influenza A; PI3 = parainfluenza 3; $\mathbf{M p}=$ Mycoplasma pneumoniae. 
Table 2 Specimens showing significant isolations of bacteria

\begin{tabular}{|c|c|c|c|c|c|c|}
\hline & \multirow{2}{*}{\multicolumn{2}{|c|}{$\begin{array}{l}\text { Throat swab } \\
(n=70)\end{array}$}} & \multicolumn{4}{|c|}{ Sputum samples } \\
\hline & & & \multicolumn{2}{|c|}{ 1st $(n=70)$} & \multicolumn{2}{|c|}{$2 n d(n=53)$} \\
\hline & No. & $\%$ & No. & $\%$ & No. & $\%$ \\
\hline $\begin{array}{l}\text { S. aureus } \\
\text { S. pyogenes } \\
\text { S. pneumoniae } \\
\text { H. influenzae }\end{array}$ & $\begin{array}{r}11 \\
8 \\
0 \\
0\end{array}$ & $\begin{array}{l}(16) \\
(11) \\
(0) \\
(0)\end{array}$ & $\begin{array}{l}6 \\
1 \\
3 \\
2\end{array}$ & $\begin{array}{l}(9) \\
(1) \\
(4) \\
(3)\end{array}$ & $\begin{array}{l}2 \\
0 \\
1 \\
0\end{array}$ & $\begin{array}{l}(4) \\
(0) \\
(2) \\
(0)\end{array}$ \\
\hline Total & 19 & (27) & 12 & (17) & 3 & (6) \\
\hline
\end{tabular}

were similar to those recovered in 7 virus-negative episodes. There was no clear association between individual viruses and bacteria except perhaps in the case of influenza virus; in 3 of the 7 episodes in which influenza was the only virus found, bacteria were present in sputum ( $S$. aureus twice and $S$. pneumoniae once), compared with isolation of bacteria from sputum in only 3 out of 20 episodes showing rhinovirus (S. aureus, $H$. influenzae, and $S$. pneumoniae, each once). There was no clear correlation between the bacterial isolation rate from first sputum specimens and the severity of illness, the rates in mild, moderate, and severe episodes being respectively $1(6 \%)$ of $18,7(29 \%)$ of 24 , and $4(13 \%)$ of 30 . In 38 episodes in which pharyngitis occurred and throat swabs were cultured, 13 (34\%) of these swabs showed pathogenic bacteria $(S$. pyogenes 7 times and $S$. aureus 6 times). Seven of the 11 febrile children had bacterial infections. Both cases of sinusitis were associated with $S$. pyogenes and one of the two cases of otitis media showed $S$. pneumoniae.

Antibacterial agents were prescribed at the time of the first visit in 30 episodes but the cultures subsequently showed that bacterial infection had been present in only 9 of these episodes, 5 of the relevant first sputum samples being positive, and 7 of the throat swabs. No initial antibacterial therapy was given in 42 episodes, and only one second sample from these episodes contained bacteria ( $S$. aureus) which had not been present in the first sample. Both first and second sputum samples were examined bacteriologically in 50 episodes of which 22 were treated with antibiotics at the time of the first visit and 28 were not. The bacterial isolation rate from first sputum samples was $14 \%$ in both the treated and the untreated group. In the second samples the rates fell in both groups, to 5 and $7 \%$ respectively.

Cytology. The cells classified as macrophages contained foamy and particulate material and were considered by the cytologist to be alveolar in origin. The relative frequency of the various cell types appeared to be little influenced by the agent isolated (Table 3) and there was no significant correlation between any of the cytological findings and severity. Bronchial epithelial cells in second sputum samples were more common in 'bacteria-positive' than in 'bacteria-negative' episodes, but numbers were small and the differences not significant. Both leucocytosis and eosinophilia graded as significant were less common in second samples than in first, and the decrease in eosinophils occurred both in the presence and absence of corticosteroid treatment. In 48 episodes both first and second sputum samples were examined cytologically. In 21 such episodes initially treated with antibiotics, $81 \%$ of first samples showed leucocytosis compared with $33 \%$ of second samples (and this difference was significant, $P<0.01, \chi^{2}$ test). In 27 episodes not treated with antibiotics the rates in first and second samples were 74 and $52 \%$ respectively $\left(P>0 \cdot 05, \chi^{2}\right.$ test).

Table 3 Percentage of sputum samples showing significant cytological abnormalities in episodes categorised according to the microbiological findings

$\%$ of sputum samples showing an abnormal content* of indicated cell types

\begin{tabular}{|c|c|c|c|c|c|}
\hline \multirow[b]{2}{*}{$\begin{array}{l}\text { Microbiological } \\
\text { findings during } \\
\text { the episodes }\end{array}$} & \multirow[b]{2}{*}{$\begin{array}{l}\text { No. of } \\
\text { samples examined }\end{array}$} & & & & \\
\hline & & $\begin{array}{l}\text { Bronchial } \\
\text { epithelial cells }\end{array}$ & Macrophages & Leucocytes & Eosinophils \\
\hline $\begin{array}{l}\text { Virus-positive } \dagger \\
(n=35)\end{array}$ & $\begin{array}{ll}1 \text { st, } & 33 \\
2 \text { nd, } & 27\end{array}$ & $\begin{array}{l}48 \\
44\end{array}$ & $\begin{array}{l}48 \\
52\end{array}$ & $\begin{array}{l}82 \\
59\end{array}$ & $\begin{array}{l}61 \\
30\end{array}$ \\
\hline $\begin{array}{l}\text { Virus-negative } \\
(\mathrm{n}=37)\end{array}$ & $\begin{array}{ll}\text { 1st, } & 37 \\
\text { 2nd, } 23\end{array}$ & $\begin{array}{l}43 \\
39\end{array}$ & $\begin{array}{l}54 \\
70\end{array}$ & $\begin{array}{l}76 \\
26\end{array}$ & $\begin{array}{l}59 \\
43\end{array}$ \\
\hline $\begin{array}{l}\text { Bacteria in } \\
\text { sputum } \ddagger(n=13)\end{array}$ & $\begin{array}{lr}\text { 1st, } & 13 \\
2 \text { nd, } & 7\end{array}$ & $\begin{array}{l}54 \\
71\end{array}$ & $\begin{array}{l}38 \\
43\end{array}$ & $\begin{array}{l}85 \\
57\end{array}$ & $\begin{array}{l}62 \\
14\end{array}$ \\
\hline $\begin{array}{l}\text { No bacteria in } \\
\text { sputum }(n=59)\end{array}$ & $\begin{array}{ll}\text { 1st, } & 57 \\
\text { 2nd, } & 43\end{array}$ & $\begin{array}{l}44 \\
37\end{array}$ & $\begin{array}{l}54 \\
63\end{array}$ & $\begin{array}{l}77 \\
42\end{array}$ & $\begin{array}{l}60 \\
40\end{array}$ \\
\hline
\end{tabular}

*Defined in Methods, tvirus recovered from one or more of the specimens originating in the episode, łsignificant isolation of bacteria from either first or second sputum specimen from the episode. 
Atopy. 14 episodes in the 5 nonatopic children were compared with 58 in the 17 atopic children. Significant eosinophilia in sputum was less common in the nonatopic children ( $43 \%$ of 14 episodes) than in the atopic group (78\% of 58 episodes); the virus isolation rate was higher in the nonatopic $(71 \%$ of 14 episodes) than in the atopic children ( $43 \%$ of 58 episodes). Both of these differences were significant $\left(\mathrm{P}<0 \cdot 05, \chi^{2}\right.$ test $)$ although the statistical comparison was somewhat unsatisfactory as one atopic child contributed 9 episodes and one, who was nonatopic, contributed 15 . The individual virus isolation rates in these 2 children were $7(78 \%)$ of 9 episodes in the nonatopic child and $6(40 \%)$ of 15 episodes in the atopic child. The serum immunoglobulin $A$ of each of these children was at the lower limit of the normal range for his age.

\section{Discussion}

Eadie et al. (1966), Stenhouse (1967), and Stott et al. (1968) found that rhinoviruses could be isolated from sputum of bronchitic adults, sometimes in high titre. Lambert and Stern (1972) cultured sputum and nasal and throat swabs from two asthmatic subjects, one of whom was a child, and recovered virus in 5 of 11 exacerbations. In the present study of wheezy bronchitis of childhood a virus was isolated from $49 \%$ of episodes, and the sputum samples collected within 5 days of onset of symptoms gave a virus isolation rate of $41 \%$. These figures are probably an underestimate of the true incidence of viral infection as our techniques may have failed to detect some rhinovirus strains, which are particularly difficult to cultivate, as well as coronaviruses. The latter are known to be important in this condition (McIntosh et al., 1973).

In previous studies, Horn et al. $(1975,1979)$ showed that rhinoviruses were the agents most often isolated from the upper respiratory tract during attacks of wheezy bronchitis; in the present study these viruses were found even more commonly in sputum, especially in severe episodes. Although the volume of sputum cultured for virus was probably greater than the volume of nasal secretions, the frequency of isolation of rhinovirus from sputum and the speed with which the cpe developed in the cultures strongly suggested that more virus was present in the lower than in the upper respiratory tract and that its detection in sputum was not simply due to contamination with upper respiratory secretions. As in earlier studies (Horn et al., 1975, 1979) influenza virus was found relatively rarely (in 9 of 72 episodes), although the frequency will naturally depend in part on the epidemic prevalence of influenza at the time of study. It remains uncertain whether influenza viruses have less propensity for causing wheeze than rhinoviruses.

There was little evidence to suggest that bacterial infection was a frequent initiating cause of wheezy bronchitis. Pathogenic bacteria were found in $27 \%$ of throat swabs, but the same organisms were rarely found in sputum. The clinical suspicion of bacterial infection raised in a proportion of the episodes by severe pharyngitis, high pyrexia, or otitis media was confirmed by bacteriological tests in about half the cases; secondary bacterial infection was uncommon regardless of antibiotic treatment. The results gave little justification for the use of routine antibacterial treatment in the absence of specific indications, although it was noted that the decrease in leucocytosis in second sputum samples was more pronounced in antibiotic-treated than in untreated episodes.

Our evidence shows that virus infects the lower as well as the upper respiratory tract in many episodes of wheezy bronchitis. The bronchial epithelial cells and inflammatory cells found in sputum confirm that the lower respiratory tract is infected, and the evidence therefore suggests that the bronchoconstriction occurring in wheezy bronchitis is produced by mechanisms initiated locally. It is not known whether rhinovirus infection in normal children extends to the lower airways although the symptoms to which it gives rise are confined to the upper respiratory tract. Direct evidence is impossible to obtain because sputum is not produced by normal children. Indirect evidence suggests that viral invasion may occur in the absence of lower respiratory symptoms, since Cate et al.(1973), Fridy et al. (1974), Blair et al. (1976), and Hall et al. (1976) all showed minor abnormalities of peripheral airways function in normal adults with colds. The abnormality of the child who develops wheezy bronchitis during virus infection may therefore be associated not so much with the presence of virus in the lower respiratory tract as with its excessive replication there and the effect of this on his already increased liability to bronchoconstriction. This view is compatible with the findings of Empey et al. (1976), who showed that the bronchoconstrictor response to histamine in normal subjects with colds was greater than in those without. These authors suggested that the response of the asthmatic, whose airways epithelial receptors are already sensitised, is an exaggeration of the normal.

Allergic factors may clearly also be relevant to the aetiology of childhood wheezy bronchitis; many of the patients are atopic and the present study shows that viral infection is often associated with sputum eosinophilia. A link between mechanisms of allergy and viral infection, at least in atopic subjects, has been given by Ida et al. (1977) who showed that 
incubation of human leucocytes with virus in vitro enhanced their release of histamine when they were subsequently exposed to ragweed antigen or antihuman IgE.

The findings in this study suggest that children subject to wheezy bronchitis may be regarded as abnormal not only in their exaggerated bronchoconstrictor response, but also in the profuseness of viral replication in the lower respiratory tract, with its accompanying inflammatory reaction. The reason for excessive virus growth at this site is not clear but may possibly be related to defects of immunity, such as local IgA deficiency. A study of immunoglobulins in sputum might be profitable when sufficiently standardised techniques become available.

We acknowledge generous grants to M.E.C.H. from the Board of Governors, Brompton Hospital, National Heart and Chest Hospitals. We thank Dr Ian Gregg for helpful criticism of the manuscript, Dr J. B. C. Evelegh, Dr A. G. Huff, and Dr. L. Burt of Roehampton, London, whose patients we studied, Mrs José Wilson for physiotherapy and collection of sputum samples, Miss D. Coombs for cytological studies, Mrs M. V. Chadwick for bacteriological investigations, and Mrs Pat Muir and Mr Arthur Miller for virological assistance.

\section{References}

Blair, H. T., Greenberg, S. B., Stevens, P. M., Bilunos, P. A., and Couch, R. B. (1976). Effects of rhinovirus infection on pulmonary function of healthy human volunteers. American Review of Respiratory Diseases, 114, 95-102.

Cate, T. R., Roberts, J. S., Russ, M. A., and Pierce, J. A. (1973). Effects of common colds on pulmonary function. American Review of Respiratory Diseases, 108, 858-865.

Eadie, M. B., Stott, E. J., and Grist, N. R. (1966). Virological studies in chronic bronchitis. British Medical Journal, 2, 671-673.

Empey, D. W., Laitinen, L. A., Jacobs, L., Gold, W. M., and Nadel, J. A. (1976). Mechanisms of bronchial hyperreactivity in normal subjects after upper respiratory tract infection. American Review of Respiratory Diseases, 113, 131-139.

Fridy, W. W., Jr, Ingram, R. H., Jr, Hierholzer, J. C., and Coleman, M. T. (1974). Airways function during mild viral respiratory illnesses. The effect of rhinovirus infection in cigarette smokers. Annals of Internal Medicine, 80, 150-155.
Godfrey, S., Kamburoff, P. L., and Nairn, J. R. (1970). Spirometry, lung volumes, and airway resistance in normal children aged 5 to 18 years. British Journal of Diseases of the Chest, 64, 15-24.

Hall, W. J., Douglas, R. G., Jr, Hyde, R. W., Roth, F. K., Cross, A. S., and Speers, D. M. (1976). Pulmonary mechanics after uncomplicated influenza $\mathbf{A}$ infection. American Review of Respiratory Diseases, 113, 141-147.

Horn, M. E. C., and Gregg, I. (1973). Role of viral infection and host factors in acute episodes of asthma and chronic bronchitis. Chest, 63, Supplement, 44-48.

Horn, M. E. C., Brain, E., Gregg, I., Yealland, S. J., and Inglis, J. M. (1975). Respiratory viral infection in childhood. A survey in general practice; Roehampton 19671972. Journal of Hygiene, 74, 157-168.

Horn, M. E. C., Brain, E. A., Gregg, I., Inglis, J. M., Yealland, S. J., and Taylor, P. (1979). Respiratory viral infection and wheezy bronchitis in childhood. Thorax, 34, 23-28.

Ida, S., Hooks, J. J., Siraganian, R. P., and Notkins, A. L. (1977). Enhancement of IgE-mediated histamine release from human basophils by viruses: role of interferon. Journal of Experimental Medicine, 145, 892-906.

Lambert, H. P., and Stern, H. (1972). Infective factors in exacerbations of bronchitis and asthma. British Medical Journal, 3, 323-327.

McIntosh, K., Ellis, E. F., Hoffman, L. S., Lybass, T. G., Eller, J. J., and Fulginiti, V. A. (1973). The association of viral and bacterial respiratory infections with exacerbations of wheezing in young asthmatic children. Journal of Pediatrics, 82, 578-590.

Minor, T. E., Dick, E. C., De Meo, A. N., Ouellette, J. J., Cohen, M., and Reed, C. E. (1974). Viruses as precipitants of asthmatic attacks in children. Journal of the American Medical Association, 227, 292-298.

Mitchell, I., Inglis, H., and Simpson, H. (1976). Viral infection in wheezy bronchitis and asthma in children. Archives of Disease in Childhood, 51, 707-711.

Stenhouse, A. C. (1967). Rhinovirus infection in acute exacerbations of chronic bronchitis: a controlled prospective study. British Medical Journal, 3, 461-463.

Stott, E. J., Grist, N. R., and Eadie, M. B. (1968). Rhinovirus infections in chronic bronchitis: isolation of eight possibly new rhinovirus serotypes. Journal of Medical Microbiology, 1, 109-117.

Strizova, V., Brown, P. K., Head, B., and Reed, S. E. (1974). The advantages of HeLa cells for isolation of rhinoviruses. Journal of Medical Microbiology, 7, 433-438.

Correspondence to Dr Sylvia E. Reed, MRC Common Cold Unit, Harvard Hospital, Coombe Road, Salisbury, Wiltshire SP2 8BW.

Received 12 December 1978 